Deniz Artun*

\title{
Am I Obliged to Imitate You? On Copying the Grande Odalisque for the Ottoman Collection of Paintings Elvah-ı Nakşiye
}

DOI 10.1515/asia-2016-0039

\begin{abstract}
In 1813, Caroline Murat, the Queen of Naples and Napoleon's youngest sister, commissioned Jean-Auguste Ingres, the director of Villa Medici at the time, a painting (Ingres 1994: 66). It was upon this commission that Ingres created in Rome, the future icon of orientalism: La Grande Odalisque. The most reproduced masterpiece of the Louvre, second only to the Mona Lisa, La Grande Odalisque was copied by a "young Turk", Haşmet Aral in 1951. Aral was sent to Paris with a state scholarship aimed at expanding his expertise in painting and this time it was his commission to paint the Odalisque. Upon his return, his copy was represented in the museum of copies, an initiative launched in 1915 by historian and museologist Halil Edhem, brother of celebrated Osman Hamdi, and expanded by several of his followers. This paper will bring to the foreground Haşmet Aral's encounter as a copyist of Odalisque, with the views of Lhote and Leger, the masters he worked with in Paris, on the task of copy and Ingres. It will also dwell on the "achievements" of Aral as compared to other copyists and interpreters of the Ingres' masterpiece among whom are Delacroix, Picasso, Matisse and Modigliani. And finally it will bring on the agenda the context and possible effects of the inclusion of La Grande Odalisque to the collection of a museum in Istanbul, the old capital of the Orient, at a time when orientalism was not yet criticised.
\end{abstract}

Keywords: Jean Auguste Dominique Ingres, Murat, grande odalisque, carte de copiste, art education, atelier, Adolphe Thiers, Halil Edhem, Elvah-1, Nakşiye, Haşmet Aral

The Queen of Naples, Caroline Murat, ${ }^{1}$ was the sister of Emperor Napoleon Bonaparte and the wife of King Joachim Murat. It was rumoured that she was

1 1782-1839, Queen of Naples (1808-1815).

*Corresponding author: Deniz Artun, Director, Nev Gallery, Galeri Nev, Gezegen Sokak 5, GOP, 06700, Ankara, Turkey. E-mail: denizartun@galerinev.com 
unhappy in her marriage because she regarded her brother's political power as being greater than that of her husband, so she found solace in decorating palaces. She also regarded the brushwork of French painters as being superior, and, secretly from her brother, ${ }^{2}$ took many important paintings with her to Italy as part of her dowry when she became queen and left the Elysée. ${ }^{3}$ However, in December 1814, a very short while after she had finally hung, next to others, "that" painting which she had commissioned from Jean-Auguste Dominique Ingres, the French Painter who lived in Rome, she was forced to leave Italy without looking back.

La Grande Odalisque (Figure 1) - perhaps the most famous among women who do look back - would stay in the "petits appartements", the most modest of the Murat residences, there on the wall where it was carefully placed as a pendant to La Dormeuse de Naples purchased previously, again from Ingres. While the "Grande" Dormeuse - thought to have been a portrait of a sleeping woman with her right arm languidly resting above her head - had her eyes closed, ${ }^{4}$ the Grande Odalisque must have witnessed the invasion of the palace by rebels and the disappearance of some of the paintings from the Murat collection. Indeed, the Dormeuse has never been seen since. As for the Grande Odalisque, which the Murats left behind in May 1815 together with their power and without having paid it off, it mysteriously reappeared in September of the same year on

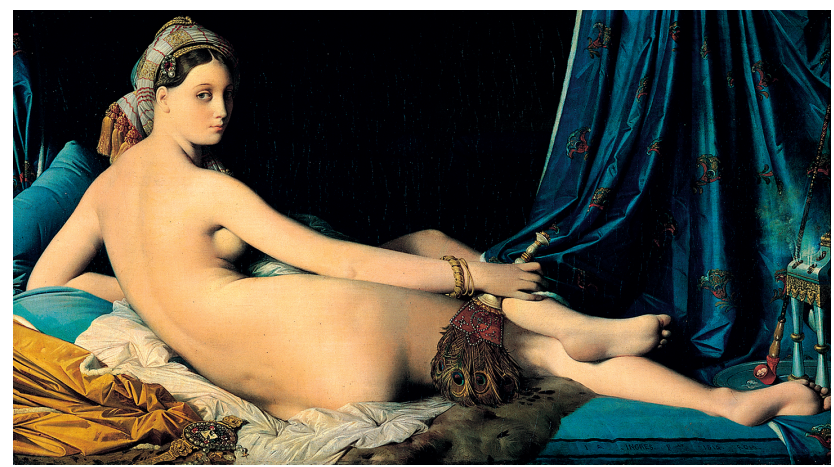

Figure 1: Jean Dominique Ingres, La Grande Odalisque, $88.9 \times 162.56 \mathrm{~cm}$, oil on canvas, 1814 , Musée du Louvre, Paris.

2 For the things Caroline did behind Murat's and her brother's back, including secretly pushing the latter to cheat on Josephine, see Vidal, 2006.

3 At that time the Elysée Palace was the property of Joachim Murat, who later sold it to Napoléon.

4 Based on the artist's surviving study for the painting. 
the wall of France's newly appointed ambassador to the Two Sicilies. ${ }^{5}$ Having heard the news, Ingres wrote a letter to the ambassador, in which he tried to convince him not only to return the painting to him, but also, interestingly, that the woman portrayed was not Queen Caroline Murat. ${ }^{6}$

It is a copy that proves that the ambassador answered the letter affirmatively and that the painting - which was signed and dated 1814 by Ingres and handed over to the king and queen - was returned to the artist shortly after. This copy was signed Atala Stamaty and dated 1816. The note on it read: "d'après le tableau peint par Ingres à Rome/Odalisque,"7 thus giving the painting its name. Ingres had allowed Atala, the young daughter of the Stamaty family who were his close friends in Rome, to come to his studio and work on the details of the figure. In the meantime, together with the head and shoulders of theOdalisque that she had baptized, Atala Stamaty virtually shaped her fate as well: to be copied. What's more, when Ingres wrote in his letter to the French ambassador, "my model was not Caroline Murat, as people suppose, but a tenyear-old girl," he might have been speaking of Atala who was exactly ten years old when the painting was first done. ${ }^{8}$ So perhaps, the first copyist of the Odalisque - by then an adolescent - had copied her own image.

\section{A sin against antiquity}

The person who first made a copy of the entire Odalisque painting was Ingres himself. One year after Stamaty, he produced a "petite" Odalisque 9 measuring $12.5 \times 22.8 \mathrm{~cm}^{10}$ (Figure 2). The meticulousness he applied in this copy has led art historians to believe that it might, once again, have been commissioned by an important collector. ${ }^{11}$ The size was not the only thing that Ingres changed when reproducing this painting. Some of the details in the small painting and the accessories worn by the figure have also been altered. Immediately afterward, in

5 The Count Narbonne-Pelet.

6 This was one of two known letters; Salmon 2006: 22.

7 "after a painting made by Ingres in Rome/Odalisque".

8 Salmon 2006: 24.

9 "small Flemish and Dutch paintings are excellent models to capture the color and effect of a history painting. In this regard, one can learn much from them and take them as models" (Ingres 1994: 56).

10 The original dimensions of the Grande Odalisque were $91 \times 162 \mathrm{~cm}$.

11 Salmon 2006: 26. 


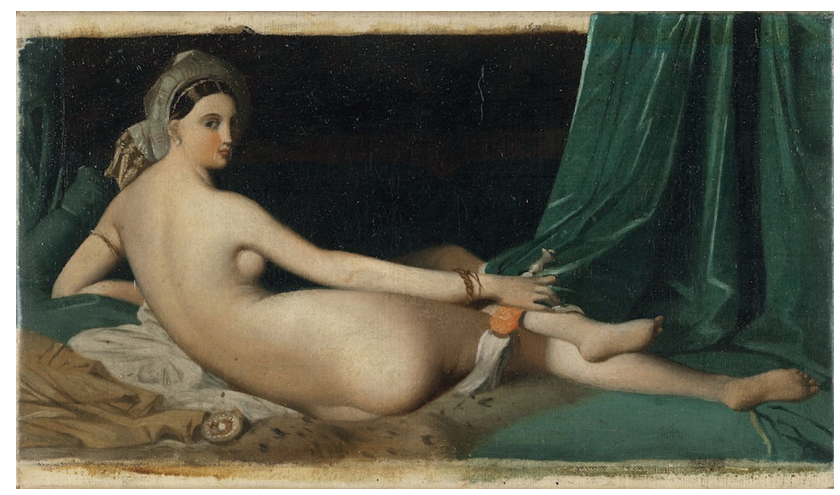

Figure 2: Jean Dominique Ingres, La Grande Odalisque, $14.3 \times 24.3 \mathrm{~cm}$, oil on canvas, private collection, Paris.

1818, Ingres produced a copy of the first copy of the Odalisque. This head of Odalisque, ${ }^{12}$ which adds to the historical significance of the Stamaty drawing, is now preserved in the Louvre. Ingres would later reproduce two more versions of his own version of the head, while the complete painting was reproduced, again by Ingres himself, at least four more times throughout the 1820s. In each of these versions, the artist would alter one or more objects, details of the setting, jewellery worn by the model, or his colour palette.

Originally intended for the private quarters of the Queen of Naples, Une Odalisque was first exhibited in a public gallery in 1819 at the annual Salon held in the Louvre. This meant not only that it could be seen by everybody, but also that it could be copied by everybody. The first complete and faithful reproduction of the Odalisque by another artist was in the album "Essais lithographiques sur l'exposition au Musée Royal de l'année 1819" and done by one of the best-known painters of historical scenes at the time, Alexandre-Marie Colin. Another one was accompanied by the rather bitter commentary ${ }^{13}$ of the Louvre's paintings conservator, Charles-Paul Landon, who prepared the catalogue for the Salon. The former was a black-and-white lithograph and the latter a black-andwhite engraving. Certainly Ingres himself would also try the technique of printmaking to reproduce the painting. In 1825, he made a mirror-image lithograph of the Odalisque, once again with changes in the setting and details. The second mirror-image lithograph is signed Jean-Pierre Sudre and dated 1826. ${ }^{14}$ Known as one of the most scrupulous copyists of the master, Sudre also made a print of the

12 "une jolie autocitation" (a nice self-citation), Cuzin/Salmon 2006: 33.

13 The engraving was by Charles Normand.

14 Salmon 2006: 37. 
head of the Odalisque a year later. Sixteen years later, in 1843, he would repeat this copy but this time posed in reverse, thus bringing his faithfulness to perfection. In the meantime, in 1828, the first print by Sudre was recopied by another artist using the eau-forte technique and would feature in an illustrious album that brings together major paintings from European collections. ${ }^{15}$

At a date that cannot be determined exactly, but is known to be after the 1819 Salon, the Odalisque was purchased by a private collector ${ }^{16}$ at almost half the price set for the Murats and was hung in the collector's hôtel particulier in Paris. The painting that was criticized even for being featured at the Salon in 1819 was only a decade later ranked among European masterpieces despite the fact that it was kept in a private collection and only seen by a few privileged visitors. This must have been because of the images of the Odalisque ceaselessly reproduced and distributed by its copyists. While the painting was dismissed in 1819 as a sin that Ingres "committed against the pure style of antiquity," reproduction realized by the painter himself would that same year be described as the Raphaelesque fruit of the pure brush of "our Ingres" at the Salon. ${ }^{18}$

The nineteenth century stereotype of the Odalisque was further reinforced when the first collector to own the work decided while he was still alive and he still retained his interest in collecting to sell it in 1850 for an unknown reason - perhaps simply because he was tempted by its value, which had increased due to its popularity. Indeed, the purchaser of the work was none other than Adolphe Goupil, reputed as "the greatest art dealer of the century." 19 In the late 1850s, gallery owner and print editor Goupil would have the first ever photograph taken of the work itself, followed by the photograph of Sudre's lithograph. From these photographs, he would obtain hundreds of prints on diverse materials, from the most ordinary to the most exclusive, and duplicated and marketed these by the thousands. When Charles Baudelaire, the first to be captivated by the sensuality of the work, referred to it as "Grande Odalisque" in the article he wrote in 1846 about an exhibition, the "greatness" of the work could no longer be questioned. After changing hands several more times, it was acquired by the Louvre in 1899 and the Odalisque which has "neither bones, nor muscles, nor blood, nor life" 20 was

15 Achille Reveil.

16 Comte James-Alexandre de Pourtalès-Gorgier.

17 Salmon 2006: 30-31.

18 Salmon 2006: 40.

19 The Ottoman court was among Goupil's customers; he sold them two of Gérôme's orientalist works. On Goupil, his commercial talent and his relations with the Ottoman court see LafontCouturier 2000.

20 Salmon 2006: 30. 
described anew as one of the greatest nudes, not only of the history of French art but of the world.

\section{To be original by imitating}

The first Paris Salon in which Jean-Dominique Ingres participated after 1819 was in 1824. The oil painting The Vow of Louis XIII, which was featured here and lauded for its references to Raphael, is considered the turning point in his career. ${ }^{21}$ Encouraged by the success of this painting, which had been commissioned by the French state, Ingres would finally move back to Paris. What's more, he decided to "officially" accept as his students, young people like Atala Stamaty who were eager to work in his studio. He taught numerous young painters in his private studio between 1825-1834, and at the École des BeauxArts between 1829-1851, albeit intermittently. These lessons were based on making copies from engravings in the studio and from originals at the Louvre where they were frequently required to go. ${ }^{22}$ It is known that the master even went in person to the Directorate of the Louvre and asked them to issue a carte de copiste for each of his apprentices so that they could complete their tasks. ${ }^{23}$ Thus, the young artists could spend as much time as needed in front of a work.

No doubt the selection of works from which they were to make copies was also one of the keys to their education. Ingres suggested fifteenth- and sixteenthcentury Italian masters, and especially the "god-man" Raphael. ${ }^{24} \mathrm{He}$ advised those who went to the Louvre to cross the other halls "wearing blinders" and to go straight ahead to the end without stopping. In Ingres's time, Raphael's paintings were at the very end of the Louvre's long galleries. ${ }^{25}$

"Do you think that I send you to the Louvre to find what is conventionally called 'ideal beauty,' something different from what is in nature?... I send you to the Louvre because you will learn from the antique to see nature.... Do you think

21 Amaury-Duval 1993: 25.

22 The first stage would involve copying prints by masters; this would be followed by other copies drawn after sculpture casts. Students would then make drawings from live models. Only if there was time left and, more importantly, if the student was exceptionally talented, would they go on to paint. In his manuscript published in 1864, Ingres wrote that if he had to put a sign over the door to his studio he would write: "École de dessin" (Drawing School); "and I am certain that I would, indeed, create painters.” (Ingres 1994: 41).

23 Amaury-Duval 1993: 426.

24 Amaury-Duval 1993: 32; Ingres 1994: 78.

25 Amaury-Duval 1993: 150. 
that in ordering you to copy them I want to turn you into copyists? No, I want you to get the juice of the plant. Address yourself to the masters, therefore, speak to them, they will answer you, for they are still living. It is they who will instruct you; I myself am no more than their quiz-master."26

Ingres too made copies from works by the Italian painters, especially Raphael. ${ }^{27}$ Although these spanned various stages of his career - indeed, it is known that his last drawing before dying was a copy of Giotto $^{28}$-, the greatest number of studies were, of course, from his years in Rome. ${ }^{29}$ While speaking of one of his early works, he said that he had been deceived about what he had learned before going to Italy, and that his true education began once he went there: "They had tricked me, and I had to begin my education all over again. I, sirs, followed the path of the masters, of Raphael."30 Yet in his writings on art he warns: "One must not think that the exclusive love I have for this painter [Raphael] causes me to ape him; which would be such a difficult thing indeed, even impossible. I think I would know how to be original by imitating." 31

\section{I sign them: Ingres}

In 1835, Jean Dominique Ingres would return to Italy, to his masters. This time around he was no longer a young painter, but the director of the French Academy in Rome. ${ }^{32}$ He was appointed by his friend, the historian, occasional art critic, and bureaucrat Adolphe Thiers, who was the Minister of Interior at that time. It was also Thiers who commissioned paintings for the state and had come to be known as the "sovereign master of artists" 33 due to his generosity in the

26 Ingres 1994: 59.

27 For the most known examples see Amaury-Duval 1993: 99-101.

28 Amaury-Duval 1993: 50.

29 Ingres won the Prix de Rome in 1801; however, due to certain arrangements that the Ministry of Economy was forced to make, he would have to wait five years before going to Rome. After finally going to Italy in 1806, he spent a total of eighteen years there, fourteen of which he spent in Rome and his last four years in Florence.

30 Amaury-Duval 1993: 34.

31 Ingres, 1994: 8. A similar quote: "Never draw from nature, young man. It has nothing to teach us about expression. Always copy line from the drawing of great masters of the past, this is how one learns to be oneself." (Prouvost d'Agostino, 2006: 61).

32 1835-1841.

33 Amaury-Duval 1993: 96-97. 
matter. All these capacities and powers led Thiers to believe that he could ask Ingres while he was in Rome to make copies of Raphael's Transfiguration and especially his frescoes in the Vatican Stanze. Thiers's dream was to establish a collection of copies of masterpieces by Italian painters and sculptors reproduced in their original size for the École des Beaux-Arts and to transform this into a 'Museum of Copies' without delay. Ingres's reply was indignant and determined:

"Of course, everybody knows that I do not think myself lowered in making a sketch or a drawing after the masters; but then I make it for myself, as a student who wants to know more. However, asking me to make a drawing after another artist, me, director of the École, to go to the Vatican with a portfolio under my arm!... I answered him: "Monsieur le ministre, now, when I make drawings I sign them Ingres!”34

On the other hand, he believed in the collection of copies, perhaps even more than Thiers himself; he believed that this collection should consist predominantly of examples from Italian painters, and that those of Raphael in particular should be in the majority. For Ingres, studying at the École des Beaux-Arts was not a requirement; he criticized many of the principles related to the functioning of the institution, and above all, the fact that the chefs d'ateliers changed periodically such that teachers and students were never able to develop a true master-apprentice relationship. But going to Rome was a must: Rome was superior to everything, Paris followed behind! $!^{35}$ Therefore, those who did not win the Prix de Rome or did not wish to enter the contest, should go there at all costs, even if it was with the support of their family. ${ }^{36}$ And, to Ingres, for those who could not even find this support, bringing Rome to Paris was crucial.

Therefore, it did not take him long to turn the commissions that felt like insults to him into an honoring opportunity for the young students surrounding him. In 1835, a short time after Ingres had been appointed in Rome, his pupils from his private studio, the painter Paul Balze and his young brother Raymond Balze, would take on the task of making copies of all the frescoes in the Vatican Stanze and Loggie. It took them two years to complete the copies of the Loggie (1835-1847) and eight to finish the copies of the Stanze (1840-1847). ${ }^{37}$ The copies were brought to Paris in 1874; they were first exhibited at the Panthéon and later in the chapel of the École des Beaux-Arts where they are still preserved today.

34 Amaury-Duval 1993: 257.

35 Ingres 1994: 11.

36 Amaury-Duval 1993: 173.

37 Amaury-Duval 1993: 154. 
Thiers also allocated a significant budget for the École des Beaux-Arts to expand its collection of sculpture casts, which had already been of considerable size because it had been developed from drawings of casts, a practice that constituted an important part of studio training. It was once again Ingres who would be the one to monitor the selection of sculptures from Antiquity and the Renaissance that were to be copied from Rome. At times he would criticize the ministry, and when decisions were finalized, it was him who would have his students execute the copies. $^{38}$

\section{Osman Hamdi's ultimate goal ${ }^{39}$}

While Paris's reference was Rome, for Istanbul Rome was Paris. In Istanbul, a single person led a similar mission to that of copying Rome to Paris which was carried out in unison, albeit with occasional conflicts, by Jean-Dominique Ingres and Adolphe Thiers.

Halil Edhem Bey, who was born in 1861, was the younger brother of the painter, educator, museologist, and archaeologist Osman Hamdi Bey. Trained as a chemist and geologist, Halil Edhem completed his studies at universities in Zurich, Vienna, and Bern. He returned to Istanbul in 1884 and worked in his field for a long time. So it comes as a surprise that in 1892, he "made a radical change in his career" 40 when he was appointed assistant to his brother Osman Hamdi Bey, the director of the Imperial Museum (Müze-i Hümayun). When Osman Hamdi Bey, who was nineteen years his senior, died in 1910, Halil Edhem took over the two important positions held by his brother and became director of both the Imperial Museum and of the Academy of Fine Arts (Sanayi-i Nefise Mektebi).

The first endeavor he undertook that very same year was to secure the necessary budget from the Chamber of Deputies to have copies made of the works of Western masters - Osman Hamdi's "ultimate goal, which he pursued until his death." 41 Thus, especially between 1910-1913, a period when the budget was relatively high, he himself selected many works from the museums

38 Amaury-Duval 1993: 263.

39 This chapter was published in 2014 as part of my article "Démocrite: Elvah-1 Nakşiye Koleksiyonu için Louvre'dan Bir Sipariş" (Démocrite: A Commission from the Louvre for the Collection of the Imperial Museum of Istanbul) in: Semra Germaner Armağanı, Banu Mahir (ed.), İstanbul: Mimar Sinan Üniversitesi Güzel Sanatlar, 54-68.

40 Eldem 2010: 255-260.

41 Edhem 1970: 39. 
in Berlin, Madrid, Munich, Paris, and Vienna ${ }^{42}$ and had them copied. Adding these to original works gathered from living Ottoman artists, he established the first "modern" collection ${ }^{43}$ in Istanbul, the Elvah-1 Nakşiye (The Collection of Paintings).

The painter Sami Yetik, in his article "For the Academy of Fine Arts", 44 which he sent on February 12, 1912 from Paris to the Newspaper of the Ottoman Society of Painters, mentions how Halil Bey had come to Paris for the collection of copies of the Elvah-1 Nakşiye. The newly appointed director had contented himself with commissioning French copyists to make copies of certain paintings by the "celebrities" in the Louvre Museum, whereas what they had expected was a "sovereign master", just like Thiers. Sami resented that neither artists in Istanbul, nor Ottomans working in France at that time were deemed worthy of the task.

It is likely no coincidence that the next issue of the newspaper published on March 25, 1912, features an article by Vahid Bey, the art history teacher of the Academy of Fine Arts, explaining the details of Halil Edhem's “copy” project. Vahid Bey writes that, of the thirty-five copies gathered until then, four had been realized by Ottoman artists and that one of them even bore the signature of a painter who was a graduate of the Academy of Fine Arts; "a great source of pride" for them. Furthermore, Vahid Bey emphasizes in his article that they aimed to attain a few hundred copies within two or three years, virtually offering consolation to Ottoman artists who had not been commissioned yet, and, to quote Sami, whose "amour propre had been wounded." 45

With the advent of the First World War, the generous budget allocated to the copies by the Chamber of Deputies was reduced to nearly ten percent of its original size, and, in 1916, allocation of a special budget for this purpose was abandoned altogether, ${ }^{46}$ which surely slowed down the development of the collection. In the article he wrote for the catalogue of the Elvah-1 Nakşiye, Halil Edhem states that the year the catalogue was published, i. e. 1924, the

42 According to Halil Edhem's own statement, the decision was made to commission copies from Rome as well, however the Tripoli Battle between the Italians and the Ottomans left this city of Ingres off the list. (Edhem 1970: 40).

43 On Müze-i Humayun organized as a modern museum of Istanbul under the curatorship of Halil Edhem see Ali Artun (2010) "Halil Edhem'in Modern İstanbul Müzesi” (The Modern Museum of Halil Edhem).

44 Sami (2007): "Sanayi-i Nefise Mektebi İçin” in: Osmanl Ressamlar Cemiyeti Gazetesi: 19111914, İstanbul: Kitap Yayınevi, 87-89.

45 Vahid (2007): “Müze-i Hümayun’da Bir Şube-i Cedide-i Sanat,” “Sanayi-i Nefise Mektebi İçin” in: Osmanl Ressamlar Cemiyeti Gazetesi: 1911-1914, İstanbul: Kitap Yayınevi, 109.

46 Edhem 1970: 39-40. 
number of copied works was forty-two and that ten of these had been executed by "artists who are our citizens." "47 Thirteen of these works were from the collections of the Louvre Museum, and of the thirteen works, seven were done by young Ottoman artists who were in Paris at that time. As for the French copyists, they consisted of a total of three painters who each undertook a number of the commissions. While all copyists in Berlin, Madrid, and Vienna were foreign, Halil Edhem preferred to have "his citizens" execute the majority of works selected from Paris. Thus, Sami’s concerns were groundless.

What, however, is really cause for concern is that Halil Edhem died in 1938 without bringing his brother Osman Hamdi Bey's wish and his own ultimate efforts to fulfillment. Moreover, exactly ten years later, in 1948, the big fire that broke out in the Academy caused great damage to what had been gathered from the work commissioned to Ottoman and foreign painters until then. ${ }^{48}$ Therefore, the fact that the generation of artists who went or were sent to Paris immediately after the fire ${ }^{49}$ set up their easels in the Louvre Museum without delay can be interpreted as an effort to keep alive the legend of Halil Edhem - who had only died recently when they entered the Academy - and to realize an ideal that had haunted them since their years as students. ${ }^{50}$ Indeed, the works they submitted to the collection of copies of the Academy when they returned in 1951 and 1952, were the last additions to the collection. ${ }^{51}$ It is important to take note that the "copy" project ended with the post-Second World War generation ${ }^{52}$ who would

47 Edhem 1970: 40. (Although Halil Edhem states that there are 42 of them, the number of copies listed on the catalogue is 43,11 among these being realized by Ottoman artists.)

48 Hüseyin Gezer recalls how reproductions donated by "the French" from the Louvre had also been destroyed in the fire. (Çakır Aydın (ed.) 2003: 68).

49 Among them were Eren Eyüboğlu, Feyhaman Duran, Haşmet Akal, Maide Arel, Neşet Günal, and Zeki Faik İzer.

50 When he said "The Academy is on fire!" we climbed the slopes of Findıklı. From there we cried over our past; our whole life was at the Academy!” said Bedri Rahmi (one of their teachers from the Academy). Many of our paintings had also burned. We were students, but of course the paintings of the teachers were very important (Adnan Çoker in Çakır Aydın (ed.) 2003: 167).

51 Another anecdote by Adnan Çoker can give an idea about the importance of replacing the reproductions which were kept at the Academy for making copies: "They had asked the Louvre for a hundred and seventy sculpture casts commissioned from Paris - casts large and small, including sculptures two meters high. They had mentioned the fire at the Academy, that everything had been destroyed, and this is why they were donating these hundred and seventy pieces." Çoker continues to recount his memories by telling how, in March or April of 1951, just before graduating, they waited on a foggy Istanbul morning for the arrival of the casts on the quay of the Academy; and how it had been forbidden to copy them out of fear that they might be damaged again, so they had "first-hand" copies made, and students would work by making copies from these copies (Çakır Aydın (ed.) 2003: 168).

52 Among them were Selim Turan, Hakkı Anlı, Nejad Devrim and Mübin Orhon. 
go to Paris right in the middle of the century, not to copy but to create; not to return but to stay and participate.

\section{He could not live if he did not go to Paris!}

On May 22, 1950, Haşmet Akal, one of the last missionaries of the collection of copies, got one of those carte de copiste (Figure 3) that Ingres had once

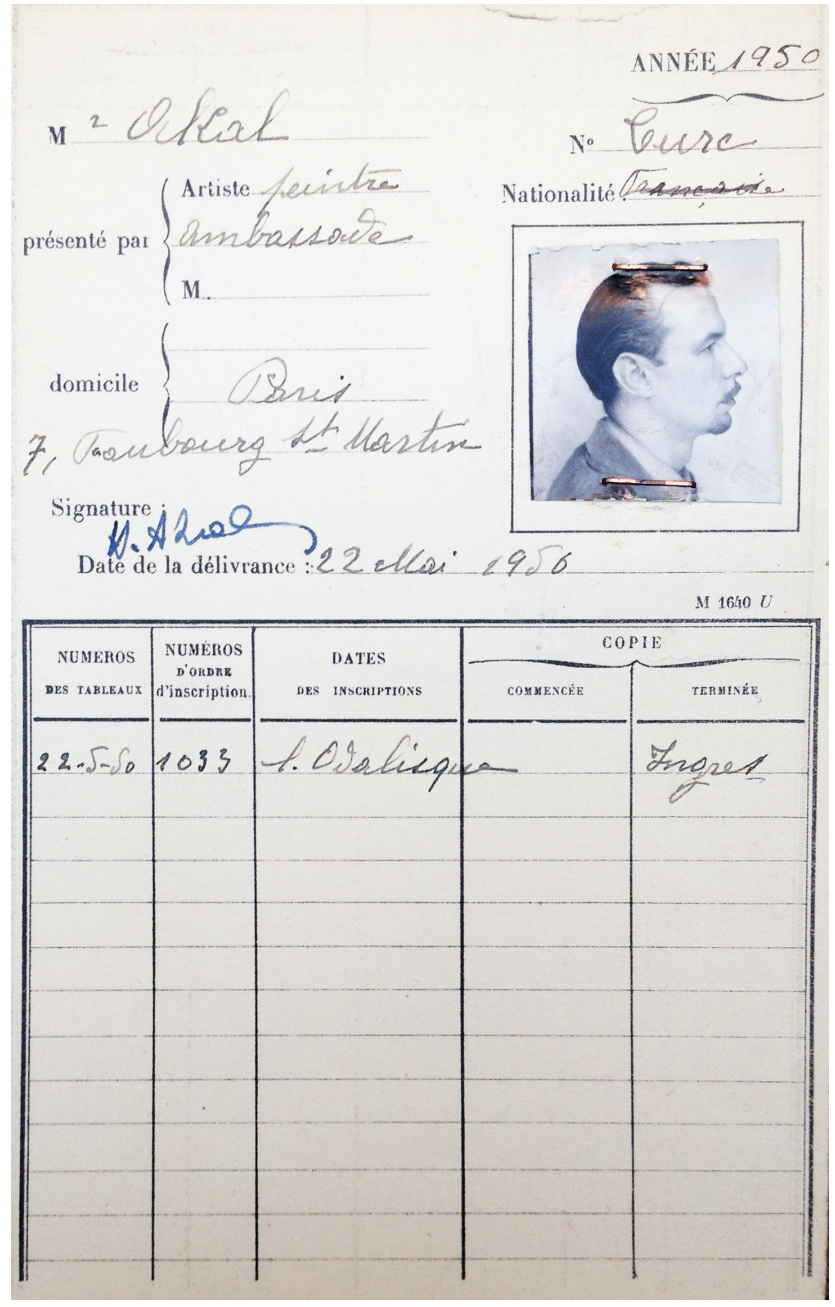

Figure 3: Haşmet Akal, Carte de Copiste, 1950, Archives du Louvre, Paris. 
obtained for his students by special permission and found himself faced with the Grande Odalisque. Akal was born in 1918; he had enrolled in the Painting Department of the Academy in Istanbul in 1938, the very year that Halil Edhem died; he had graduated in 1946. Aziz Nesin, in an article he wrote about his friend Haşmet Akal, says: “He couldn't live if he didn't go to Paris”. Like Ingres, who, despite having been trained in Paris at the Beaux-Arts, believed he received his education in Rome and advised everyone to go to Rome for a true education in art, Akal, a graduate of the Istanbul Academy of Fine Arts, had to go to Paris; he had to be there and mature there. "He couldn't live if he didn't go to Paris. That's what he said. He was leaving his two children, his wife, his mother behind for this cause. He was completely possessed by the magic and the passion of art”.

For Haşmet Akal, the formula for this magic was no doubt to attend the studio of André Lhote (Figure 4). Through his writing, Lhote took Cubism beyond the period during which it prevailed in Paris; he took it beyond the French borders, especially through his studio classes where he mostly taught foreign students. During the years following the founding of the Republic of Turkey, for those who went from Istanbul to Paris, "the torch of art" was in his hands and in his academy. ${ }^{53}$ This torch was passed from generation to

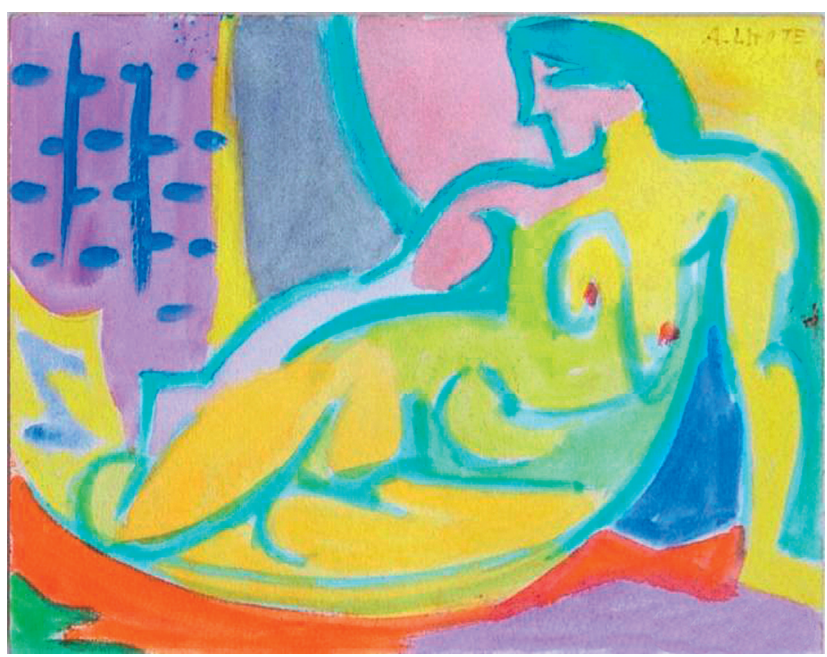

Figure 4: André Lhote, Odalisque, $12 \times 16 \mathrm{~cm}$, watercolor on paper, private collection.

53 Görele (1938): 5-6. 
generation. However, when it was the turn of Akal's generation, the Cubism of "Group D", founded by those who held the torch just before them, was a rather "formalist" interpretation of the teachings of Lhote. ${ }^{54}$ In 1940, Akal and his friends would come together and respond to their predecessors, emphasizing on 'social content. ${ }^{55}$ Thus, the "Group Yeniler" (Group of Innovators/ Newcomers), of which Akal was a part, took over "Group D”s claim to bring the "living", "new" art from Paris. For an "innovator" like Akal, what had called him to Paris at the cost of selling his and his father's house was Lhote's "Socialist" and "Realist" Cubism. In the teachings of Lhote, contrary to common belief, the means of establishing a relationship between art and society was not Cubist murals but education in painting. ${ }^{56}$

André Lhote found Picasso's or Braque's Cubism too abstract or conceptual. In order to direct this movement into the course of a more "realist" tradition, he established his own school in 1925, after having taught in a great number of private art schools. This school, which continued until the death of the artist in 1962, was known as the "Stronghold of Cubism." Here, "the teachings of Lhote were based on knowledge of the rules of composition learned from the masters". This cubist doctrine would also serve to glorify French art in the eyes of young foreigners who had come to Paris. After all, to quote Lhote, "the work of art, a reflection of the universal order, expresses reality by means of plastic analogies. [...] these formulas, or 'plastic invariables' based on geometry, are the same in all eras and all civilizations". 57

Among copyists and interpreters of the Odalisque before or after Akal are Vallotton, Modigliani, De Chirico, Lempicka, Raysse, Souzouki, Festa, Ramos, Rauschenberg, Pettibone, and Romberg. It is said that a photograph of the work was hung in the studio of Picasso ${ }^{58}$ who made two copies of the Odalisque; one in pencil (1917) and the other in ink and gouache (1907). The earlier colored copy, which art historians believe was painted in front of the original, is a precursor bearing the first signs of cubism. "The face is absent [...] It's already the cubist gaze!"59 There is no doubt that Braque's Femme nue assise, de dos drew its inspiration from the Odalisque. What is more, André Lhote, who was perhaps the most active exponent of cubism and

54 Founded by painter Nurullah Berk, Abidin Dino, Zeki Faik İzer, Elif Naci, Cemal Tollu, and sculptor Zühtü Müridoğlu in 1933, "Group D” interpreted Cubism as a method of geometric forming rather than a method of breaking up objects (Rona/Beykan 1997: 416-417).

55 Ferruh Başağa in Aydın 2003: 25.

56 Lhote 1946: 108.

57 Lhote 1946: 104-105.

58 Cuzin/Salmon 2006: 152.

59 Cuzin/Salmon 2006: 150-151. 
Haşmet Akal's teacher in Paris, declared this painting - which was once considered unacceptable for having two vertebrae too many and one of the breasts under the armpit - a "classic"!60

According to Lhote, those who thought otherwise could only be supporters of Academism, who by now had fallen out of favor. Of course Ingres was not ignorant of anatomy; being a student of David must have made him, from his earliest years, virtually as knowledgeable in anatomy as a surgeon. It is childish to argue that he tried to attract attention by intentionally exaggerating mistakes; accusing the work of insincerity would also mean denying its sincerity. Whereas, the Odalisque is the fruit of the master's deeply felt sincerity, his fierce love. The opposite could only come out of the cold hands of a real surgeon and not those of a painter passionate about his model. There is no need to attach importance to precision; nobody cares about blind Realism. All that is needed is to approach the human body with pure sensitivity. According to Lhote's observations, Ingres's mind followed his heart and the deformations highlight virtually all of the details that seduced him on a woman's back. He allowed the marks and impressions within him to guide his brush and was thus an ancestor of Impressionism. Indeed, Ingres was the predecessor not only of the Cubists, but of Monet and Cézanne as well. What is in his painting is not a mistake that needs to be corrected but a formula to be discovered; ${ }^{61}$ a geometric rhythm that Lhote's students had to examine continually. But only those who look with eyes wide open will be able notice it all.

Was it André Lhote who told Haşmet Akal to look at Ingres, to look with eyes wide open, to set it into his memory as if he was to copy it with his eyes closed? Was it Lhote who chose "that" painting for his student? Lhote himself would write that he repeated the pose with twenty different models yet he was never able to copy the expression on the face of the Odalisque. ${ }^{62}$ On the other hand, if you ask art historians, Lhote's most obvious copy of Ingres is not the repetition of just any painting but it is Lhote's studio itself: "He opens a studio [...] frequented by docile imitators, but also by young demanding artists who understood that Lhote was appealing to their culture and their originality. How does one not think of the Ingres studio?". ${ }^{3}$

60 Cuzin/Salmon 2006: 150.

61 Déformer le modèle (to deform the model), Lhote 1946: 56-59.

62 Lhote 1946: 59.

63 Cuzin/Salmon 2006: 152-153. 


\section{L'Ingrisme is a common language $^{64}$}

The Louvre Museum's archival records show that on June 14, 1950, twenty-three days after Haşmet Akal obtained a carte de copiste on May 22, 1950 to make a copy of the Odalisque by Jean-Dominique Ingres; Neşet Günal, another student of André Lhote, had also received permission for the same work. According to his carte de copiste, Odalisque was one of three copies on which Neşet Günal worked. The other two were from Titian and Rousseau and were included in the Academy's collection; however, it was decided that the Odalisque would be represented in Istanbul under Akal's signature (Figure 5).

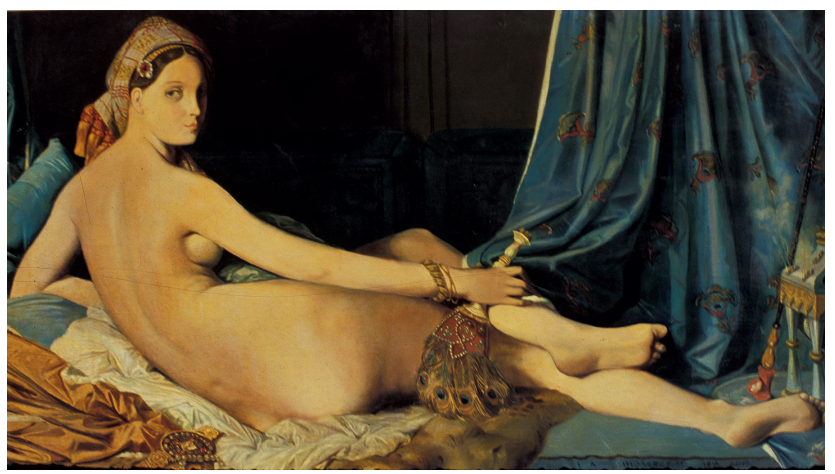

Figure 5: Haşmet Akal, La Grande Odalisque, $83 \times 145.5 \mathrm{~cm}$, oil on canvas, 1950, Mimar Sinan Fine Arts University Collection, Istanbul.

The relationships between the works and the copyists are thought-provoking; especially, following the death of Halil Edhem, when we have a lot fewer clues on how these works were selected and how they were paired with their copyists. Was copying Ingres an act of worship for Akal, as was copying Raphael for Ingres? ${ }^{65}$ Should we mention Haşmet Akal among copyists of Ingres; a list that consists of dozens of artists, and, even if we focus solely on French painting, includes "giants" such as Delacroix, Bouguereau, Gérome, Cézanne, Seurat, Courbet, Renoir, Degas, Bonnat, Matisse, Gaugin, and Toulouse-Lautrec? Or, when we focus solely on Turkish painting, could he be compared to Abidin

64 Cuzin/Salmon 2006: 102.

65 Ingres, we saw it in Rome, constantly copies drawings and paintings by Raphael; he assimilates his physical types, his manner of linking forms together, his rhythms - which, dare we say, are strong, full, and soft (see Cuzin/Salmon, 2006: 51). 
Dino, Adnan Çoker, Necla Rüzgar, or Taner Ceylan; painters whom we know made copies of Ingres after Akal?

Close to a hundred years after the Odalisque was separated from its first “companion” La Dormeuse de Naples, Edouard Manet's Olympia was purchased by the Louvre Museum and was hung as a pendant to the Odalisque in the Salle Denon. ${ }^{66}$ Not only were the two paintings hung on either side of a door, at equal distance from the ledge, they have also been paired by a great number of writers and critics of art history; what one has in excess has almost always been explained by what the other lacks. How should one interpret the fact that, while Halil Edhem was still alive, Halil Dikmen, one of André Lhote's first students, entered the Salle Denon using a card similar to that of Haşmet Akal, and made a copy for the Elvah-1 Nakşiye, not of the Odalisque but of the Olympia (which itself could be considered a "copy" of the Odalisque)? The Odalisque is a gem, not only of Western history or French art, but of the Orientalist corpus as well. And perhaps, it is precisely for this reason that, in order for a modern young painter to pick up his brush and move to Istanbul, it had to wait to be designated as a reference, not to Orientalism but to Impressionism, and especially to Cubism.

On the one hand, a Museum of Copies conceived by Adolphe Thiers in Paris, a city laden with many masterpieces which reference one another and thus weave the Western history of art; on the other the Museum of Copies that Halil Edhem dreamed of for Istanbul. Are these as alike as they seem at first glance? And is it a simple coincidence that could be explained by bureaucratic mishaps that both museums never saw the light of day and that the copies were left to accumulate in the storage rooms of the academies in Paris and Istanbul?

When going to Italy, Caroline Murat smuggled in under her skirt what she wanted to see and preserve from French painting, while Haşmet Akal wanted to take home inside his jacket postcards of the masterpieces of the Louvre which he hadn't had time to copy. ${ }^{67}$ Could these be read as anecdotes about how

66 After Manet's death, the first one to buy his painting was Monet. In 1890, he donated the Olympia to the official government in order to have it displayed in the museum by a fait accompli. However, the state kept the work out of sight until 1898. It was eventually hung in the Luxembourg Museum in 1898, and then in the Louvre in 1907.

67 "One day we went to the Louvre together. In one hall they were selling reproductions of the works in the museum. As Haşmet was going through these, he said: 'Urall, could you snitch a reproduction from here?' I answered: 'Don't worry, I'm the best guy to do that'. Of course he thought I was joking, but a few steps out of the museum he asked me what I had done. When I told him coolly to check his right side pocket, at first he didn't believe me; but when he did what I said, he looked in amazement at the fifteen or so reproductions in his hand." (Urallı 1961: 13). 
museums of copies are not imagined only by "countries" and that people also construct and deconstruct imaginary museums?

Every time the Odalisque is copied, each time she turns and looks at her copyists who closely examine her every bone, new questions are added to these and their answers are hidden in the slight differences which all her copyists, beginning with Ingres, altered intentionally or unintentionally. The final sentence of the manifesto of "Group D," to which Haşmet Akal was opposed, is as follows: "No one person sees the same thing as another person." Can any one work be copied identically?

\section{Bibliography}

Amaury-Duval, Eugène Emmanuel (1993): L'Atelier D'Ingres: Édition critique de l'ouvrage publié à Paris en 1878. Paris: Arthena.

Artun, Ali (8 November 2010): “Halil Edhem'in Modern İstanbul Müzesi”. In: Osman Hami Bey’in 100. Yıl Dönümü Sempozyumu. İstanbul: Mimar Sinan Güzel Sanatlar Üniversitesi.

Artun, Deniz (2014): “Démocrite: Elvah-ı Nakşiye Koleksiyonu İçin Louvre'dan Bir Sipariş”. In: Semra Germaner Armağanı. Edited by Banu Mahir. İstanbul: Mimar Sinan Güzel Sanatlar Üniversitesi, 54-68.

Aydın, Mukadder Çakır (ed.) (2003): Akademiye Tanıklık I: Resim ve Heykel. İstanbul: Bağlam Yayınları.

Cuzin, Jean-Pierre / Salmon, Dimitri (ed.) (2006): Ingres: Regards Croisés. Paris: Editions Mengès.

d'Agostino, Pierre Emmanuel Prouvost (2006): Ingres: Grande Odalisque. Paris: Les Quatres Chemins.

Edhem, Halil (1970): Elvah-ı Nakşiye Koleksiyonu. İstanbul: Milliyet Yayınları.

Eldem, Edhem (2010): Osman Hamdi Bey Sözlüğü. İstanbul: Kültür ve Turizm Bakanlığı Görele, Hamit (1938): “Julian Akademisi”. AR Issue 19: 5-6.

Ingres, Jean Dominique (1994): Écrits sur L'Art: Dessins de L'Ingres. Paris: Bibliothèque des Arts. Lhote, André (1946): Ecrits sur la Peinture. Bruxelles: Editions Lumière.

Rona, Zeynep / Beykan, Müren (eds.) (1997): Eczacıbaşı Sanat Ansiklopedisi. İstanbul: Yem Yayınları

Salmon, Dimitri (2006): Ingres: La Grande Odalisque. Paris: Musée du Louvre Editions.

Sami (2007): "Sanayi-i Nefise Mektebi İçin”. In: Osmanlı Ressamlar Cemiyeti Gazetesi.

İstanbul: Kitap Yayınevi, 1911-1914.

Urallı, Salih N. (1961): “Haşmet Akal'ın Ardından”. Dost Dergisi 41: 10-13.

Vidal, Florence (2006): Caroline Bonaparte: Sœur de Napoléon. Paris: Pygmalion. 